\title{
GAMBARAN PENYAKIT PENYERTA PASIEN GANGGUAN JIWA
}

\author{
${\text { Livana } \mathbf{P H}^{1} \text {, Sujarwo }}^{2}$, Siti Musyarofah ${ }^{3}$, Novi Indrayati ${ }^{1}$ \\ ${ }^{1}$ Program Studi Ilmu Keperawatan, STIKES Kendal \\ ${ }^{2}$ RSJD Amino Gondhohutomo Semarang \\ ${ }^{3}$ Program Studi Kesehatan Masyarakat, STIKES Kendal \\ livana.ph@gmail.com
}

\begin{abstract}
ABSTRAK
Manusia saat ini banyak yang mengalami gangguan, gangguan fisik ataupun mental yang akan mempengaruhi sosial dan budaya sehari-hari seorang manusia. Gangguan fisik ataupun mental dapat terjadi kepada siapa saja, yang dimana kondisi mental yang mengalami gangguan dapat mempengaruhi kesehatan fisik, sehingga tidak menutup kemungkinan seorang yang mengalami gangguan jiwa juga akan mempunyai penyakit penyerta yang lain. Tujuan penelitian ini untuk Mengetahui gambaran penyakit penyerta terbanyak di ruang Kresno RSJD Dr. Amino Gondho Hutomo Semarang. Metode penelitian yang digunakan deskriptif. Populasi dalam penelitian ini adalah semua pasien yang ada selama 6 bulan terakhir (MeiNovember) sejumlah 284 pasien. Teknik sampel dalam penelitian ini menggunakan total sampling. Adapun besar sampel dalam penelitian ini adalah 284 responden. Penelitian ini dilaksanakan di RSJD Dr. Amino Gondho Hutomo Semarang di ruang Kresno. Data dianalisis secara univariat menggunakan distribusi frekuensi. Hasil penelitian menunjukkan bahwa penyakit penyerta terbanyak pasien gangguan jiwa adalah Diabetes Melitus sebanyak 52 pasien, hipertensi sebanyak 43 pasien dan epilepsi sebanyak 40 pasien. Penelitian selanjutnya disarankan meneliti tentang faktor-faktor yang dapat mempengaruhi terjadinya penyakit penyerta pada pasien.
\end{abstract}

Kata kunci: Penyakit penyerta, pasien gangguan jiwa

\section{DESCRIPTION OF DISEASE DISEASE PATIENTS OF SOUL DISORDERS}

\begin{abstract}
Humans today have many disorders, physical or mental disorders that will affect the social and cultural everyday of a human. Physical or mental disorders can occur to anyone, where a mental condition that has an impairment can affect physical health, so that it is possible for a person who has a mental disorder to have other comorbidities. The purpose of this study was to determine the description of the most common comorbidities in the Kresno Room at the RSJD Dr. Amino Gondho Hutomo Semarang. The research method used is descriptive. The population in this study were all patients who had been in the last 6 months (May-November) totaling 284 patients. The sample technique in this study used total sampling. The sample size in this study was 284 respondents. This research was conducted at the RSJD Dr. Amino Gondho Hutomo Semarang in the Kresno room. Data were analyzed univariately using frequency distribution. The results showed that the most comorbidities of mental patients were 52 diabetes mellitus patients, 43 patients with hypertension and 40 patients with epilepsy. Further research is suggested to examine the factors that can influence the occurrence of comorbidities in patients.
\end{abstract}

Keywords: co-morbidities, mental patients.

\section{PENDAHULUAN}

Kesehatan adalah keadaan sehat fisik, mental dan sosial, bukan semata-mata keadaan tanpa penyakit atau kelemahan (WHO, 2001). Hal ini berarti seseorang dikatakan sehat apabila seluruh aspek dalam dirinya dalam keadaan tidak terganggu baik tubuh, psikis, maupun sosial. Apabila fisiknya sehat, maka mental (jiwa) dan sosialpun sehat, demikian pula sebaliknya, jika mentalnya terganggu atau sakit, maka fisik dan sosialnyapun akan sakit. Kesehatan harus dilihat secara menyeluruh sehingga kesehatan jiwa merupakan bagian dari kesehatan yang tidak dapat dipisahkan 
(Stuart \& Laraia, 2005). Manusia saat ini banyak yang mengalami gangguan, gangguan fisik ataupun mental yang akan mempengaruhi sosial dan budaya sehari-hari seorang manusia. Gangguan fisik ataupun mental dapat terjadi kepada siapa saja, yang dimana kondisi mental yang mengalami gangguan dapat mempengaruhi kesehatan fisik, sehingga tidak menutup kemungkinan seorang yang mengalami gangguan jiwa juga akan mempunyai penyakit penyerta yang lain.

Stuart dan Laraia (2005) Seseorang dikatakan sehat jiwa apabila terpenuhi kriteria memiliki perilaku positif, tumbuh kembang dan aktualisasi diri, memiliki integritas diri, memiliki otonomi, memiliki persepsi sesuai realita yang ada serta mampu beradaptasi dengan lingkungannya sehingga mampu melaksanakan peran sosial dengan baik. Maslow (1970, dalam Shives, 2005) menyatakan bahwa seseorang yang sehat jiwa mampu mengaktualisasikan dirinya yang ditunjukkan dengan memiliki konsep diri positif dan memiliki hubungan yang baik dengan orang lain dan lingkungannya, terbuka dengan orang lain, membuat keputusan berdasarkan realita yang ada, optimis, menghargai dan menikmati hidup, mandiri dalam berfikir dan bertindak sesuai dengan standar perilaku dan nilai-nilai, serta kreatif menggunakan berbagai pendekatan dalam penyelesaian masalah kesehatan jiwa.

WHO (2009) memperkirakan 450 juta orang di seluruh dunia mengalami gangguan mental, sekitar $10 \%$ orang dewasa mengalami gangguan jiwa saat ini dan $25 \%$ penduduk diperkirakan akan mengalami gangguan jiwa pada usia tertentu selama hidupnya. Usia ini biasanya terjadi pada dewasa muda antara usia 18-21 tahun (WHO, 2009). Menurut National institute of mental health gangguan jiwa mencapai $13 \%$ dari penyakit secara keseluruhan dan diperkirakan akan berkembang menjadi $25 \%$ di tahun 2030. Kejadian tersebut akan memberikan andil meningkatnya prevalensi gangguan jiwa dari tahun ke tahun di berbagai negara. Berdasarkan hasil sensus penduduk Amerika Serikat tahun 2004, diperkirakan 26,2 \% penduduk yang berusia $18-30$ tahun atau lebih mengalami gangguan jiwa (NIMH, 2011).

Prevalensi gangguan jiwa tertinggi di Indonesia terdapat di provinsi Daerah Khusus
Ibu kota Jakarta (24,3\%), diikuti Nagroe Aceh Darussalam (18,5\%), Sumatera Barat $(17,7$ $\%)$, NTB (10,9\%), Sumatera Selatan $(9,2 \%)$ dan Jawa Tengah $(6,8 \%)$ (Depkes RI, 2008). Berdasarkan data Riset Kesehatan Dasar (2007), menunjukkan bahwa prevalensi gangguan jiwa secara nasional mencapai 5,6\% dari jumlah penduduk, dengan kata lain menunjukkan bahwa pada setiap 1000 orang penduduk terdapat empat sampai lima orang menderita gangguan jiwa. Berdasarkan dari data tersebut bahwa data pertahun di Indonesia yang mengalami gangguan jiwa selalu meningkat, dengan peningkatan tersebut akan menyebabkan seseorang dengan gangguan jiwa dapat mengalami penyakit penyerta antara lain hipertensi, diabetes mellitus, febris dan lainlain. Penyakit penyerta ini juga dapat mempengaruhi psikis dan fisik seseorang. Hasil observasi di ruang Kresno banyak sekali penyakit penyerta pada pasien yang dirawat antara lain epilepsi, CHF, hipertensi, diabetes melitus dan lain-lain. Ruang Kresno merupakan salah satu ruangan yang terdapat di RSJD Dr. Amino Gondohutomo Semarang yang merawat pasien dengan double diagnostic, dimana pasien yang mengalami gangguan jiwa juga mengalami penyakit penyerta misalnya febris, fraktur dan diabetes mellitus. Pada pasien dengan gangguan jiwa banyak sekali faktor pencetus yang menimbulkan penyakit penyerta antara lain gaya hidup, pola makan dan obat-obat kejiwaan yang dikonsumsi mereka. Beberapa obat kejiwaan dapat meningkatkan kadar gula dalam darah sehingga pasien gangguan jiwa dapat mengalami peningkatan kadar gula dalam darah yang akan menyebabkan diabetes mellitus.

Diabetes mellitus (DM) merupakan salah satu penyakit yang prevalensinya semakin meningkat dari tahun ke tahun. Wordl Health Organization (WHO) memprediksi kenaikan jumlah pasien diabetes di Indonesia dari 8,4 juta pada tahun 2000 menjadi sekitar 21,3 juta pada tahun 2030, bahkan Indonesia menempati urutan keempat di dunia sebagai jumlah penderita diabetes mellitus terbanyak setelah India, China, dan Amerika (Pratiwi, 2007). Pengobatan diabetes memerlukan waktu yang lama (karena diabetes merupakan penyakit menahun yang akan diderita seumur hidup) dan sangat kompleks (tidak hanya membutuhkan pengobatan tetapi juga perubahan gaya hidup) sehingga seringkali pasien tidak patuh dan cenderung menjadi 
putus asa dengan program terapi yang lama, kompleks dan tidak menghasilkan kesembuhan. Menurut Asti (2006) umumnya penderita diabetes patuh berobat kepada dokter selama ia masih menderita gejala yang subjektif dan mengganggu hidup rutinnya sehari-hari, begitu ia bebas dari keluhankeluhan tersebut maka kepatuhannya untuk berobat berkurang (Pratiwi, 2007). Hasil penelitian di beberapa negara, ketidakpatuhan pasien diabetes dalam berobat mencapai 4050\%. Menurut laporan WHO pada tahun 2013, kepatuhan rata-rata pasien pada terapi jangka panjang terhadap penyakit kronis di negara maju hanya sebesar $50 \%$ dan di negara berkembang jumlah tersebut bahkan lebih rendah. Tahun 2006 jumlah penderita diabetes Indonesia mencapai 14 juta orang, dari jumlah itu baru $50 \%$ penderita yang sadar mengidap dan sekitar $30 \%$ diantaranya melakukan pengobatan secara teratur (Delamater, 2009; Pratiwi, 2007).

Berdasarkan masalah diatas, kami ingin mengetahui gambaran penyakit penyerta pada pasien yang dirawat di ruang Kresno RSJD Dr. Amino Gondo Hutomo Semarang selama 6 bulan terakhir. Kami memilih mengambil data selama 6 bulan terakhir karena penyakit penyerta pada pasien yang dirawat lebih signifikan dalam hal membandingkan penyakit yang satu dengan penyakit yang lain.

\section{METODE}

Metode penelitian yang digunakan deskriptif. Populasi dalam penelitian ini adalah semua pasien yang ada selama 6 bulan terakhir (MeiOktober) sejumlah 284 pasien. Teknik sampel dalam penelitian ini menggunakan total sampling. Adapun besar sampel dalam penelitian ini adalah 284 responden. Penelitian ini dilaksanakan di RSJD Dr. Amino Gondho Hutomo Semarang di ruang Kresno. Data dianalisis secara univariat menggunakan distribusi frekuensi.

\section{HASIL}

Hasil penelitia disajikan sebagai berikut :

Tabel 1

Penyakit penyerta pada pasien gangguan jiwa Mei $2017(\mathrm{n}=38)$

\begin{tabular}{llc}
\hline \multicolumn{1}{c}{ Penyakit Penyerta } & F & $\%$ \\
\hline Diabetes Mellitus & 7 & $18 \%$ \\
Hipertensi & 10 & $26 \%$ \\
Thypoid & 3 & $8 \%$ \\
DHF & 1 & $3 \%$ \\
Epilepsi & 4 & $11 \%$ \\
SNH & 2 & $5 \%$ \\
Brakikardi & 1 & $3 \%$ \\
GE & 1 & $3 \%$ \\
Febris & 2 & $5 \%$ \\
Anemia & 4 & $11 \%$ \\
VES & 1 & $3 \%$ \\
General Widnes & 1 & $3 \%$ \\
Hepatitis & 1 & $3 \%$ \\
\hline Dilihat dari tabel 1 menunjukkan bahwa & Hutomo bulan Mei 2017 menunjukkan \\
penyakit penyerta pada pasien gangguan jiwa & distribusi terbanyak yaitu pada Hipertensi \\
di ruang Kresno RSJD Dr. Amino Gondo & sebanyak 10 kasus.
\end{tabular}


Tabel 2.

Penyakit penyerta pada pasien gangguan jiwa Juni $2017(\mathrm{n}=79)$

\begin{tabular}{|c|c|c|}
\hline Penyakit Penyerta & $\mathrm{F}$ & $\%$ \\
\hline Diabetes Mellitus & 11 & $14 \%$ \\
\hline Hipertensi & 14 & $18 \%$ \\
\hline Thypoid & 4 & $5 \%$ \\
\hline DHF & 1 & $1 \%$ \\
\hline Epilepsi & 14 & $18 \%$ \\
\hline SNH & 5 & $6 \%$ \\
\hline Febris & 7 & $9 \%$ \\
\hline Anemia & 7 & $9 \%$ \\
\hline Hepatitis & 1 & $1 \%$ \\
\hline Leukositosis & 1 & $1 \%$ \\
\hline TB Paru & 3 & $4 \%$ \\
\hline VES trigemini & 1 & $1 \%$ \\
\hline Diare & 1 & $1 \%$ \\
\hline CKR & 2 & $3 \%$ \\
\hline Hiperkalemia & 2 & $3 \%$ \\
\hline Brpn & 2 & $3 \%$ \\
\hline Hipoalbumin & 1 & $1 \%$ \\
\hline Selolitis & 1 & $1 \%$ \\
\hline Hipoglikemia & 1 & $1 \%$ \\
\hline
\end{tabular}

Tabel 3.

Penyakit penyerta pada pasien gangguan jiwa Juli $2017(\mathrm{n}=51)$

\begin{tabular}{lcc}
\hline \multicolumn{1}{c}{ Penyakit Penyerta } & Jumlah (n) & Presentase (\%) \\
\hline Diabetes Mellitus & 10 & $19 \%$ \\
Hipertensi & 7 & $13 \%$ \\
Thypoid & 2 & $4 \%$ \\
Epilepsi & 5 & $10 \%$ \\
SNH & 3 & $6 \%$ \\
Febris & 5 & $10 \%$ \\
Anemia & 4 & $8 \%$ \\
Hypertiroid & 3 & $6 \%$ \\
AMI & 1 & $2 \%$ \\
Hemoroid & 2 & $4 \%$ \\
Asma & 1 & $2 \%$ \\
TB & 2 & $4 \%$ \\
Hiperkalemia & 1 & $2 \%$ \\
Brpn & 3 & $6 \%$ \\
Selolitis & 1 & $2 \%$ \\
Hipoglikemia & 1 & $2 \%$ \\
CHF & 1 & $2 \%$ \\
\hline dari tabel 3 menunjukkan bahwa & Gondo Hutomo bulan Agustus 2017 \\
di penyerta pada pasien gangguan & menunjukkan distribusi terbanyak yaitu \\
ruang Kresno RSJD Dr. Amino & pada Diabetes Melitus sebanyak 10 kasus.
\end{tabular}


Tabel 4.

Penyakit penyerta pada pasien gangguan jiwa Agustus $2017(\mathrm{n}=36)$

\begin{tabular}{lcc}
\hline \multicolumn{1}{r}{ Penyakit Penyerta } & F & $\%$ \\
\hline Diabetes Mellitus & 10 & $28 \%$ \\
Hipertensi & 5 & $14 \%$ \\
Thypoid & 1 & $3 \%$ \\
Epilepsi & 3 & $8 \%$ \\
SNH & 2 & $6 \%$ \\
Febris & 4 & $11 \%$ \\
Anemia & 3 & $8 \%$ \\
Hypertiroid & 1 & $3 \%$ \\
Fraktur & 2 & $6 \%$ \\
TB paru & 1 & $3 \%$ \\
Diare & 1 & $3 \%$ \\
Brpn & 2 & $6 \%$ \\
Hipoglikemi & 1 & $3 \%$ \\
\hline
\end{tabular}

Dilihat dari tabel 4menunjukkan bahwa Gondo Hutomo bulan Agustus 2017 penyakit penyerta pada pasien gangguan menunjukkan distribusi terbanyak yaitu jiwa di ruang Kresno RSJD Dr. Amino pada Diabetes Melitus sebanyak 10 kasus.

Tabel 5.

Penyakit penyerta pada pasien gangguan jiwa September-Oktober $2017(\mathrm{n}=92)$

\begin{tabular}{lcc}
\hline \multicolumn{1}{c}{ Diagnosa Fisik } & $\mathrm{F}$ & $\%$ \\
\hline Epilepsi & 14 & $15 \%$ \\
DM Tipe 2 & 14 & $15 \%$ \\
Hipertensi & 7 & $8 \%$ \\
Thypoid & 8 & $9 \%$ \\
syok hipovolemik & 1 & $1 \%$ \\
SNH & 10 & $11 \%$ \\
hipotensi takikardi & 1 & $1 \%$ \\
nekrosis jaringan & 1 & $1 \%$ \\
Febris & 10 & $11 \%$ \\
Kejang & 6 & $7 \%$ \\
Leptospirosis & 1 & $1 \%$ \\
Vomitus & 1 & $1 \%$ \\
Anemia & 6 & $7 \%$ \\
Hepatitis & 2 & $2 \%$ \\
DHF & 3 & $3 \%$ \\
Bronkopneumonia & 2 & $2 \%$ \\
TB Paru & 2 & $2 \%$ \\
Hipokalemia & 2 & $2 \%$ \\
CKR & 1 & $1 \%$ \\
\hline ang Kresno RSJD Dr. Amino Gondho & didapatkan data bahwa diagnosa penyerta \\
mengalami gangguan jiwa disertai & terbanyak yaitu DM Tipe 2 dengan jumlah 14 \\
merupakan tempat perawatan orang (15\%).
\end{tabular}


Tabel 6.

Penyakit penyerta pada pasien gangguan jiwa Mei-Oktober 2017 (284)

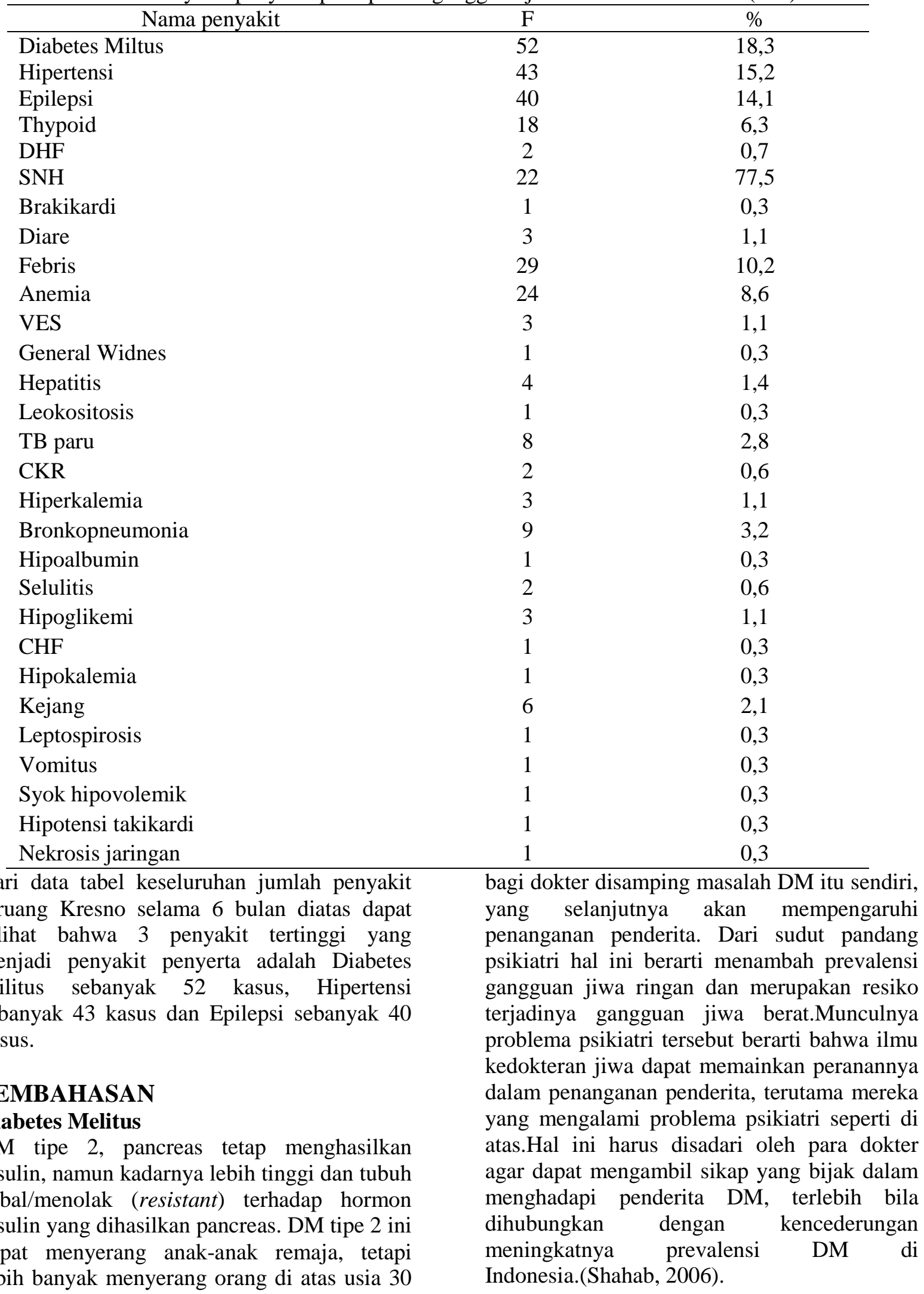
yang mungkin muncul merupakan masalah lain 
Perubahan besar terjadi dalam hidup seseorang setelah mengidap penyakit DM. Ia tidak dapat mengkonsumsi makanan tanpa aturan dan tidak dapat melakukan aktifitas dengan bebas tanpa khawatir kadar gulanya akan naik pada saat kelelahan. Selain itu, penderita DM juga harus mengikuti tritmen dokter, pemeriksaan kadar gula darah secara rutin dan pemakaian obat sesuai aturan. Seseorang yang menderita penyakit DM memerlukan banyak sekali penyesuaian di dalam hidupnya, sehingga penyakit DM ini tidak hanya berpengaruh secara fisik, namun juga berpengaruh secara psikologis pada penderita. Saat seseorang didiagnosis menderita DM maka respon emosional yang biasanya muncul yaitu penolakan, kecemasan dan depresi, tidak jauh berbeda dengan penyakit kronis lain. Penderita DM memiliki tingkat depresi dan kecemasan yang tinggi, yang berkaitan dengan tritmen yang harus dijalani dan terjadinya komplikasi serius. Kecemasan yang dialami penderita berkaitan dengan tritmen yang harus dijalani seperti diet atau pengaturan makan, pemeriksaan kadar gula darah, konsumsi obat dan juga olah raga. Selain itu, resiko komplikasi penyakit yang dapat dialami penderita juga menyebabkan terjadinya kecemasan.Murdiningsih dan Ghofur (2013), mengatakan konflik psikologis, kecemasan, depresi, dan stress dapat menyebabkan semakin memburuknya kondisi kesehatan atau penyakit yang diderita oleh seseorang. Penderita DM jika mengalami kecemasan, akan mempengaruhi proses kesembuhan dan menghambat kemampuan aktivitas kehidupan sehari-hari. Pasien diabetes yang mengalami kecemasan memiliki control gula darah yang buruk dan meningkatnya gejala-gejala penyakit (Murdiningsih dan Ghofur, 2013). Kecemasan merupakan hal yang tidak mudah untuk dihadapi oleh penderita DM. Oleh karena itu, penderita DM tentu sangat membutuhkan dukungan dari lingkungan sosialnya.

Diabetes dan gangguan kejiwaan dapat hadir dalam pola yang berbeda.Pertama, keduanya dapat hadir sebagai kondisi independen dengan koneksi langsung yang tidak jelas.Dalam skenario kedua adalah hasil dari jalur patogen yang independen dan paralel.Kedua, tentu diabetes dapat menjadi rumit dengan munculnya gangguan kejiwaan. Dalam kasus diabetes berkontribusi patogenesis gangguan kejiwaan. Berbagai faktor biologis dan psikologis menengahi munculnya gangguan kejiwaan dalam konteks seperti itu.Ketiga, gangguan kejiwaan tertentu seperti depresi dan skizofrenia bertindak sebagai faktor risiko independen yang signifikan untuk perkembangan diabetes. Keempat, mungkin ada tumpang tindih antara presentasi klinis hipoglikemik dan episode ketoasidosis dan kondisi seperti serangan panik. Kelima, toleransi glukosa terganggu dan diabetes bisa muncul sebagai efek samping dari obat yang digunakan untuk gangguan kejiwaan. Pengobatan gangguan kejiwaan dapat mempengaruhi perawatan diabetes dengan cara lain.

Risperidone adalah obat yang digunakan untuk menangani skizofrenia dan gangguan psikosis lain, serta perilaku agresif dan disruptif yang membahayakan pasien maupun orang lain. Antipsikotik ini bekerja dengan menstabilkan senyawa alami otak yang mengendalikan pola pikir, perasaan, dan perilaku. Obat ini mempunyai efek samping menaikan kadar gula darah pada orang yang mengkonsumsinya jadi disarankan untuk orang yang mendapatkan obat Risperidone ini untuk sering memeriksakan kadar gula darahnya.

\section{Hipertensi}

Perilaku kekerasan merupakan respon terhadap stresor yang dihadapi oleh seseorang yang ditunjukkan dalam perilaku aktual dalam melakukan kekerasan baik verbal maupun non verbal. Penyebab perilaku kekerasan dipengaruhi oleh beberapa faktor yaitu faktor predisposisi dan faktor presipitasi. Faktor predisposisi adalah faktor resiko yang mempengaruhi jenis dan jumlah sumber yang dapat dibangkitkan oleh individu untuk mengatasi stres. Faktor presipitasi yaitu stimulasi yang dipresepsikan oleh individu sebagai tantangan, ancaman atau tuntutan yang memerlukan energi ekstra untuk melakukan koping (PPNI Jawa Tengah, 2014).

Stres merupakan suatu respon nonspesifik dari tubuh terhadap setiap tekanan atau tuntutan yang mungkin muncul, baik dari kondisi yang menyenangkan maupun tidakmenyenangkan.Stres dapat memicu timbulnya hipertensi melalui aktivasi sistem saraf simpatis yang mengakibatkan naiknyatekanandarah secara intermiten (tidak menentu) (Andria, 2013). Pada saat seseorang mengalami stres, hormon adrenalin akan dilepaskan dan kemudian akan meningkatkan 
tekanan darah melalui kontraksi arteri (vasokontriksi) dan peningkatan denyut jantung. Apabila stresberlanjut, tekanan darah akan tetap tinggi sehingga orang tersebut akan mengalami hipertensi (South, 2014).

\section{Epilepsi}

Ilmuwan di Taiwan tahun 2014 telah menemukan bahwa skizofrenia memang sangat erat kaitannya dengan penyakit mental epilepsi. Penelitian ini telah dipublikasikan di dalam Jurnal Epilepsia, sebuah kumpulan artikel yang dikeluarkan oleh ILAE (International League Against Epilepsy). Dalam artikel tersebut dikatakan bahwa pasien skizofrenia mampu menderita epilepsi 6 kali lipat, sedangkan penderita epilepsi mampu juga menderita skizofrenia hampir 8 kali lipat.

Masyarakat lebih mengenal epilepsi dengan sebutan ayan atau sawan yang di sebabkan oleh pengaruh roh jahat, guna - guna, atau bahkan dianggap sebagai suatu kutukan (Hawari, 2010).Terdapat dua faktor pencetus epilepsi yakni faktor internal seperti stres, kelelahan, kurang tidur, siklus menstruasi dan faktor eksternal seperti alkohol berlebih, cahaya tertentu, mandi (Kasteleijnetal, 2012).Stressmerupakan suatu usaha dari tubuh untuk menyesuaikan diri baik secara fisik maupun jiwa dengan keadaan sekitarnya, apabila tidak dapat mengatasinya maka akan timbul gangguan jasmani, perilaku maupun gangguan jiwa (Maramis, 2010). Mediator stres seperti corticotropin-releasing hormone, corticosteroids, dan neurosteroids berkonstribusi terhadap patogenesis epilepsi (Joels, 2009).

Dampak dari penyakit epilepsi salah satunya dilihat dari aspek psikososial, masalah kejiwaan dan kemasyarakatan yang memiliki pengaruh timbal balik sebagai akibat terjadinya perubahan sosial atau gejolak dalam masyarakat yang dapat menimbulkan gangguan jiwa yang merupakan dampak dari penyakit epilepsi.Dari aspek ini dapat diketahui jenisnya yaitu masalah medik, psikologis, sosial dan ekonomi.Stigma negatif tersebut membuat penyandang epilepsi kerap mengalami deskriminasi, baik di dalam lingkungan sekolah, pekerjaan maupun lingkungan sekitar tempat tinggal(Maramis, 2010).

\section{SIMPULAN DAN SARAN Simpulan}

Penyakit penyerta terbanyak pasien gangguan jiwa di ruang Kresno RSJD Dr. Amino Gondho Hutomo Semarang adalah Diabetes Melitus sebanyak 52 pasien, hipertensi sebanyak 43 pasien dan epilepsi sebanyak 40 pasien

\section{Saran}

Penelitian selanjutnya disarankan meneliti tentang faktor-faktor yang dapat mempengaruhi terjadinya penyakit penyerta pada pasien.

\section{DAFTAR PUSTAKA}

Andria, K.M. (2013). Hubungan Antara Perilaku Olahraga, Stres dan Pola Makan dengan Tingkat Hipertensi pada Lanjut Usia di Posyandu Lansia Kelurahan Gebang Putih Kecamatan Sukokilo Kota Surabaya. Jurnal Promkes, Vol.1, No.2 Desember 2013.

Asti, T. (2006). Kepatuhan Pasien : Faktor Penting Dalam Keberhasilan Terapi, Info POM, Volume 7, Nomor 5, BPOM, Jakarta.

Brunner \& Suddarth, (2012). Keperawatan Medikal Bedah. Edisi 12. Jakarta: EGC.

Carpenito, L.J. (2011). Diagnosa Keperawatan: Aplikasi Pada Praktek Klinik. Edisi 6. Jakarta: EGC.

Dalami,. Ermawati. (2009). Asuhan keperawatan klien dengan gangguan jiwa. Jakarta: Trans Info Media.

Depkes RI. (2008). Profil Kesehatan Indonesia. Jakarta.

Hantoro, R. (2013). Buku Pintar Keperawatan Epilepsi. Yogyakarta: Penerbit Cakrawala Ilmu.

Hawari, D. (2010). Peran Keluarga dalam Gangguan Jiwa. Edisi 21. Jurnal Psikologi Rumah Sakit Jiwa Provinsi Jawa Barat. Bandung. http://id.wikapedia.org/wiki/jenis kelamin(diakses tanggal 4 februari 2013)

http://skripsisistikes.wordpress.com/200 9/05/03/ikpiii112/(diakses tanggal 5 Desember 2012). 
Hermawan, A. (2009). Penelitian Bisnis Paradigma Kuantitatif.Jakarta: PT. Gramedia Widyasarana Indonesia.

Hidayat, A.A. (2009). Metode Penelitian Keperawatan dan Teknik Analisa Data. Jakarta: Salemba Medika.

Long. B.C. (2006). Perawatan Medikal Bedah. Volume 1. Bandung: Yayasan Ikatan Alumni Pendidikan Keperawatan Pajajaran.

Maramis, W.F. (2010). Catatan Ilmu Kedokteran Jiwa. Edisi 2 Surabaya: Airlangga University Press.

Maramis. (2009). Catatan ilmu kedokteran jiwa. Edisi 2. Surabaya: Erlangga.

Murdiningsih, D., Ghofur, G. (2013). Pengaruh kecemasan terhadap kadar glukosa darah pada penderita diabetes melitus di wilayah puskesmas banyuanyar surakarta. Talenta Psikologi. 2(11): 180-187.

National institute of mental health(NIMH). 2011. The Numbers Count Mental Disorders in America. Di akses tanggal $28 \quad$ April 2013. http://www.nimh.nih.gov/health/publicat ions/the-numbers-count-mentaldisorders-in-america/index.shtm.

Notoatmodjo, S. (2012). Metodologi Penelitian Kesehatan. Jakarta: Rineka Cipta.

Nursalam. (2011). Konsep dan Penerapan Metodologi Penelitian Ilmu Keperawatan. Jakarta: Salemba Medika.

Pratiwi. (2007). Protein Vitamin Dan Bahan Pangan.Yogyakarta : Gajah Mada University Press.

Shahab, A. (2006). Komplikasi Kronik DM Penyakit Jantung Koroner. Dalam
Buku: Ajar Ilmu Penyakit Dalam. Jilid 3. Edisi IV. Jakarta: Departemen Ilmu Penyakit Dalam Fakultas Kedokteran Universitas Indonesia. Hal: 1917.

Sjaifoellah, N. (2006). Buku Ajar Ilmu Penyakit Dalam. Jilid 1. Edisi III. Jakarta: FKUI.

Smeltzer et al. (2008). BukuAjar Keperawatan Medikal Bedah. Jakarta: Buku Kedokteran EGC.

Stuart \& Laraia. (2005). Buku Saku Keperawatan Jiwa (terjemahan). Jakarta: EGC.

Sugiyono. (2010). Metode Penelitan Kuantitatif dan Kualitatif. Bandung: Alfabeta.

Sugiyono. (2015). Metode Penelitan Pendidikan (Pendekatan Kuantitatif dan Kualitatif. Penerbit CV. Bandung: Alfabeta.

Twistiandayani dan Widati. (2013). Pengaruh terapi tough stopping terhadap kemampuan mengontrol halusinasi pada pasien skizofrenia. Prosidingkonferensi nasional PPNI Jawa Tengah 2013. Diambil dari jurnal.unimus.ac.id.Diakses pada 5 Februari 2016.

WHO. (2013). About Cardiovasculer diseases. World Health Organization. Geneva. Cited July $15^{\text {th }} 2014$. Available from URL:

http//www.who.int/cardiovasculer di seases/about $\mathrm{cvd} / \mathrm{en} / \mathrm{accessed}$ on 